\title{
Clinical impact of the rapid molecular detection of RSV and influenza A and B virus in the emergency room
}

Nicolas Yin ${ }^{1}$, Marc Van Nuffelen ${ }^{2}$, Magali Bartiaux ${ }^{3}$, Thierry Préseau ${ }^{4}$, Inge Roggen ${ }^{5}$, Sabrina Delaunoy ${ }^{1}$, Bhavna Mahadeb ${ }^{1}$, Hafid Dahma ${ }^{1}$, Laurent Busson ${ }^{1}$, Olivier Vandenberg ${ }^{6,7,8}$, Marie Hallin ${ }^{1,7}$.

1. Department of Microbiology, Laboratoire Hospitalier Universitaire de Bruxelles - Universitair Laboratorium Brussel (LHUB-ULB), Université Libre de Bruxelles (ULB), Brussels, Belgium

2. Emergency Department, Erasme University Hospital, Université Libre de Bruxelles (ULB), Brussels, Belgium

3. Emergency Department, Saint-Pierre University Hospital, Université Libre de Bruxelles (ULB), Brussels, Belgium

4. Emergency Department, Brugmann University Hospital, Université Libre de Bruxelles (ULB), Brussels, Belgium

5. Emergency Department, Queen Fabiola Pediatric University Hospital, Université Libre de Bruxelles (ULB), Brussels, Belgium

6. Clinical Research and Innovation Unit, Laboratoire Hospitalier Universitaire de Bruxelles - Universitair Laboratorium Brussel (LHUB-ULB), Université Libre de Bruxelles (ULB), Brussels, Belgium

7. Centre for Environmental Health and Occupational Health, School of Public Health, Université Libre de Bruxelles (ULB), Brussels, Belgium

8. Division of Infection and Immunity, Faculty of Medical Sciences, University College London, London, United Kingdom

\section{Abstract}

Introduction: Using respiratory viruses' rapid diagnostic tests in the emergency room (ER) could allow a better and faster clinical management. Point-of-care PCR instruments provide now results in less than 30 minutes. The objective of this study was to assess the impact of the use of the cobas ${ }^{\circledR}$ Influenza A/B \& RSV Assay for use on Roche's cobas ${ }^{\circledR}$ Liat $^{\circledR}$ instrument on the clinical management of ER patients.

Methods: Patients (adults and children) requiring admission or suffering from an underlying condition at risk of respiratory complication were prospectively recruited in the ER of four hospitals in the Brussels region. Physician's intentions regarding admission, isolation, antibiotic and antiviral use were collected before and after performing a cobas ${ }^{\circledR}$ Influenza A/B \& RSV molecular test. Additionally, a comparison of the analytical performance of this test against antigen rapid tests and viral culture was performed as well as a time-to-result evaluation.

Results: PCR yielded twice more positive results than antigen rapid diagnostic tests. It allowed a decrease in the overall need for isolation and treatment by limiting the isolation of negative patients and the antibiotic use for positive patients. Meanwhile, antiviral treatments better targeted patients with a positive influenza PCR.

Conclusion: The use of a rapid influenza and RSV molecular test improves the clinical management of patients admitted to the ER by providing a fast and reliable result. Their additional cost compared to antigen tests should be balanced with the benefit of their analytical performance, leading to efficient reductions in the need of isolation and antibiotic use. 


\section{Introduction}

The COVID-19 pandemic highlighted the need for rapid and trustworthy diagnostic tests for respiratory tract infections, to assess patients' infectiousness and to set containment measures $(1,2)$. Beforehand, authors showed that a fast and reliable diagnosis of respiratory infections improved the clinical management during the seasonal epidemics of respiratory syncytial virus (RSV) and influenza A and B viruses $(3,4)$. In Europe, before the COVID-19 pandemic, social welfare rarely took in charge the molecular diagnostic of these infections, limiting their prescription in favor of less expensive antigen tests. In Belgium for instance, SARS-CoV-2 PCR detection is now reimbursed as for RSV and Influenza A and $B$ viruses only antigen detection is (5). However, compared to RT-PCR, the sensitivity of these antigen rapid diagnostic tests was estimated as low as $53.9 \%$ in adults and $64.6 \%$ in children regarding influenza A (6) and 74\% in children regarding RSV (7); impairing considerably the clinical value of a negative result. Furthermore, clinical judgment, followed by PCR or point-of-care testing (POCT), were found to be cost-effective in a setting where influenza probability was high (8). Fast "sample-in, resultout" PCR instruments such as the Roche cobas $^{\circledR}$ Liat ${ }^{\circledR}$ analyzer are now providing point-of-care PCR results in less than 30 minutes (a run on the instrument is completed in 21 minutes once the sample is loaded; the hands-on time is approximately 5 minutes) (9). The objective of this study is to assess the impact of the use of the $\operatorname{cobas}^{\circledR}$ Liat $^{\circledast}$ Influenza A/B \& RSV assay for use on the cobas $^{\circledR}$ Liat $^{\circledast}$ instrument $^{-1}$ on the clinical management of emergency room (ER) patients requiring admission or presenting an underlying condition at risk of respiratory complication. 


\section{Methods}

\section{Population and data collection}

Patients were prospectively recruited in the ER of four hospitals located in the Brussels area, Belgium. Inclusion criteria were either a pre-test indication of hospitalization or an underlying situation at risk of respiratory complication following influenza infection as described by the European Centre for Disease Prevention and Control and the US Centers for Disease Control (age $\geq 65$ years old or $<2$ years old, pregnancy, chronic medical conditions, immunocompromised patient, etc.) $(10,11)$. When including the patient and prescribing the test, physicians indicated their intentions regarding antimicrobial treatment, isolation and hospitalization by answering a questionnaire. The same questionnaire was completed again once the PCR results were available to evaluate the post-test intentions. The informed consent of each participant or their guardian was collected. The ethics' committee of each hospital approved the study.

\section{Specimen collection and analyses}

Accepted samples were nasopharyngeal swabs in $3 \mathrm{~mL}$ of universal transport medium (UTM). Nasopharyngeal aspirates diluted with $3 \mathrm{~mL}$ of UTM were also accepted for children. Approximately $200 \mu \mathrm{L}$ were immediately used to perform a rapid PCR using the cobas $^{\circledR}$ Liat $^{\circledR}$ Influenza A/B \& RSV assay (Roche Diagnostics, Indianapolis, IN) following manufacturer's instruction in a 24/7 on-site laboratory or in a point-of-care setting. PCR results were instantly transmitted towards the result servers. PCR timeto-result was assessed for PCR realized in on-site laboratories by the delay between the prescription time indicated by the physician and the results validation time, which is the time it became available for the physician. In addition, antigen rapid diagnostic tests (RDT) were performed using Influ A+B K-Set (Coris BioConcept) for Influenza A and Influenza B detection, and RSV K-SeT (Coris BioConcept) for RSV detection on the same sample $(200 \mu \mathrm{L} /$ test). Upon arrival in the virology laboratory, $1 \mathrm{~mL}$ of UTM was also inoculated on confluent Vero (African green monkey kidney), MRC5 (human lung) and LLC-MK2 (rhesus monkey kidney) cell cultures (Vircell) in 24-well or 6-well tissue culture plates (Greiner-Bio One). Cultures were incubated at $36^{\circ} \mathrm{C}$ in a $5 \% \mathrm{CO} 2$ atmosphere for 2 weeks for the Vero and LLC-MK2 cells and 3 weeks for the MRC5 cells. The media were replaced weekly. Cultures were examined every two to three days using an inverted microscope. Hemadsorption was performed on the LLC-MK2 cells at the end of the second week of incubation.

\section{Statistical analysis}

To assess the analytical performances of the cobas ${ }^{\circledR}$ Liat $^{\circledR}$ Influenza A/B \& RSV Assay, a composite reference standard was constructed as recommended (12). Samples considered as positive for a viral pathogen were defined as those testing positive for this viral pathogen by at least 2 of the 3 techniques used, negative as those that tested negative by at least 2 of the 3 techniques. Statistical analyses were performed using Analyse-it ${ }^{\circledast}$ for Microsoft Excel v5.30.4. Proportion variations between pre-test and post-test clinical intentions were evaluated using the McNemar-Mosteller exact test. 
medRxiv preprint doi: https://doi.org/10.1101/2021.11.18.21264071; this version posted November 20, 2021. The copyright holder for this preprint (which was not certified by peer review) is the author/funder, who has granted medRxiv a license to display the preprint in perpetuity.

It is made available under a CC-BY-ND 4.0 International license .

\section{Results}

Two hundred ninety-three patients were recruited including 68 children ( $<15$ years old) (Table 1). Among them, 71 had a positive rapid PCR result for influenza A only, 10 for influenza $B$ only, 1 for both influenza $A$ and $B, 8$ for RSV and 203 were negative for all the targets. The positive agreement between PCR and RDT ranged from $36.3 \%$ (4/11) for influenza B to $62.5 \%$ (5/8) for RSV. One sample was positive for influenza A using RDT although negative using culture and PCR. Likewise, one sample was positive for influenza A using culture although negative using PCR and RDT. Thus, using the composite reference standard, PCR reached a sensitivity of $100 \%$ for the 3 viruses targeted (Table 2).

\begin{tabular}{c|ccc|} 
Age (years old) & Female & Male & Overall \\
\hline$-<15$ & 25 & 43 & $\mathbf{6 8}$ \\
$-\quad 15-70$ & 63 & 63 & $\mathbf{1 2 6}$ \\
$-\quad>65$ & 35 & 64 & $\mathbf{9 9}$ \\
\hline Overall & $\mathbf{1 2 3}$ & $\mathbf{1 7 0}$ & $\mathbf{2 9 3}$ \\
\hline
\end{tabular}

Table 1: Population characteristics

\begin{tabular}{|l|c|c|c|c|c|c|}
\cline { 2 - 7 } \multicolumn{1}{c|}{} & \multicolumn{2}{c|}{ Influenza A } & \multicolumn{2}{c|}{ Influenza B } & \multicolumn{2}{c|}{ RSV } \\
\cline { 2 - 7 } \multicolumn{1}{c|}{} & Sensitivity & Specificity & Sensitivity & Specificity & Sensitivity & Specificity \\
\hline PCR & $49 / 49(100 \%)$ & $221 / 244(90.6 \%)$ & $6 / 6(100 \%)$ & $282 / 287(98.3 \%)$ & $6 / 6(100 \%)$ & $285 / 287(99.3 \%)$ \\
\hline RDT & $34 / 49(69.4 \%)$ & $241 / 242(99.6 \%)$ & $4 / 6(66.7 \%)$ & $287 / 287(100 \%)$ & $5 / 6(83.3 \%)$ & $287 / 287(100 \%)$ \\
\hline Culture & $42 / 48(87.5 \%)$ & $241 / 242(99.6 \%)$ & $6 / 6(100 \%)$ & $284 / 284(100 \%)$ & $5 / 5(100 \%)$ & $285 / 285(100 \%)$ \\
\hline
\end{tabular}

Table 2: Compared analytical performance of the Cobas ${ }^{\circledR}$ Liat Influenza A/B \& RSV assay (PCR) with antigen test (RDT) and viral culture for the diagnostic of Influenza A, B and RSV using a composite gold standard.

Clinical intentions regarding admission were not influenced by the result of the test (Table 3$)$. However, an overall decrease of the intentions of admission in isolation (-33.3\%), antibiotic use (-16.2\%) and oseltamivir (-34.4\%) use was observed. These trends were the result of both a sharp decrease of isolation intentions for people with a negative PCR (-67.9\%) and an increase of isolation intentions for people with a positive PCR. Similarly, patients with a positive PCR were less likely to be prescribed antibiotics (-43.3\%) and oseltamivir treatment was more specifically prescribed for patients with an influenza positive PCR (+164.3\%).

Two hundreds eighty-four (97.3\%) samples were analyzed in a $24 / 7$ on-site laboratory. The median time-to-result of the PCR was of 60 minutes with a $90^{\text {th }}$ percentile of 164 minutes. 
medRxiv preprint doi: https://doi.org/10.1101/2021.11.18.21264071; this version posted November 20, 2021. The copyright holder for this preprint (which was not certified by peer review) is the author/funder, who has granted medRxiv a license to display the preprint in perpetuity.

It is made available under a CC-BY-ND 4.0 International license .

\begin{tabular}{|c|c|c|c|c|}
\hline Intention & Pre-test & Post-test & Variation & p-value* \\
\hline Admission & $175 / 261$ & $172 / 261$ & $-1.7 \%$ & 0.37 \\
\hline - $\quad$ PCR + & $45 / 78$ & $41 / 78$ & $-8.9 \%$ & 0.17 \\
\hline - $\quad$ PCR flu + & $39 / 72$ & $35 / 72$ & $-10.3 \%$ & 0.17 \\
\hline - $\quad$ PCR RSV + & $6 / 6$ & $6 / 6$ & $=$ & - \\
\hline - $\quad \mathrm{RDT}+$ & $19 / 37$ & $18 / 37$ & $-5.3 \%$ & 0.50 \\
\hline - $\quad$ PCR - & $130 / 183$ & $131 / 183$ & $+0.8 \%$ & 0.50 \\
\hline Isolation** & 78/148 & $52 / 148$ & $-33.3 \%$ & 0.0004 \\
\hline - $\quad$ PCR + & $25 / 38$ & $35 / 38$ & $+40.0 \%$ & 0.011 \\
\hline - $\quad$ PCR flu + & $20 / 32$ & $30 / 32$ & $+50.0 \%$ & 0.0065 \\
\hline - $\quad \mathrm{RDT}+$ & $12 / 16$ & $16 / 16$ & $+33.3 \%$ & 0.063 \\
\hline - $\quad$ PCR - & $53 / 110$ & $17 / 110$ & $-67.9 \%$ & $<0.0001$ \\
\hline Antibiotic use & $117 / 249$ & $98 / 249$ & $-16.2 \%$ & 0.0072 \\
\hline - $\quad$ PCR + & $30 / 75$ & $17 / 75$ & $-43.3 \%$ & 0.0036 \\
\hline - $\quad$ PCR flu + & $26 / 69$ & $14 / 69$ & $-46.2 \%$ & 0.012 \\
\hline - $\quad \mathrm{RDT}+$ & $15 / 37$ & $8 / 37$ & $-46.7 \%$ & 0.020 \\
\hline - $\quad$ PCR - & $87 / 174$ & $81 / 174$ & $-6.9 \%$ & 0.20 \\
\hline Oseltamivir use & $61 / 245$ & $40 / 245$ & $-34.4 \%$ & 0.0085 \\
\hline - $\quad$ PCR flu + & $14 / 67$ & $37 / 67$ & $+164.3 \%$ & $<0.0001$ \\
\hline - $\quad$ RDT flu + & $7 / 31$ & $24 / 31$ & $+242.9 \%$ & 0.0039 \\
\hline - $\quad$ PCR flu - & $47 / 178$ & $3 / 178$ & $-93.6 \%$ & $<0.0001$ \\
\hline
\end{tabular}

Table 3: Clinical impact of the positive (+) and negative (-) results of the PCR and antigen rapid diagnostic test (RDT) for respiratory syncytial virus (RSV), influenza $A$ and $B$ viruses (flu). ${ }^{*} \mathrm{MCNemar-Mosteller} \mathrm{exact} \mathrm{test.}{ }^{* *}$ among those with both a pre-test and post-test admission intention. 


\section{Discussion}

Previous studies already underlined the impact of the rapid detection of influenza and RSV in the management of patients (13-16). We showed that an overall significant decrease of antibiotic prescription could be obtained by providing a relevant diagnostic tool combining speed and sensitivity. The excellent sensitivity of the cobas ${ }^{\circledR}$ Liat $^{\circledR}$ assay allowed an optimized assessment of the need for isolation for the inpatients, ensuring a proper isolation for almost all infected patients, which likely led to a reduction of nosocomial transmission. Indeed, less than half of patients with a positive PCR had also a positive RDT underlining the importance to use a molecular test efficiently improving antibiotic and antiviral stewardship while offering a real assessment for the need of a costly hospitalization in isolation. However, the overall decrease of the isolation indications for patients with a negative test should be balanced with the clinical presentation of the patient to prevent the nosocomial transmission of eventual other respiratory pathogens.

In our study, the median time of response from the laboratory was 60 minutes for a less than 30-minute assay. Nevertheless, the time-to-result in this setting is dependent of the overall workload in the on-site laboratory. Using this assay as a POCT at the ER would certainly decrease the time-to-result while increasing the autonomy of the ER team regarding the general management of the workflow and the real-time adaptation of the indications depending on the current level of bed occupancy and the epidemic situation.

Such strategy has however a cost and should be further examined through a medico-economic study to better determine the optimal target population, taking into account the subsequent decrease of nosocomial outbreaks and the targeted use of individual protection equipment and antibiotics. In a Dutch study, the daily direct cost of isolating patients ranged from $€ 28$ to $€ 41$ (18). At the time of writing, the price of the $\operatorname{cobas}^{\circledR}{ }^{\circledR}$ Liat $^{\circledR}$ Influenza A/B \& RSV was $39 € /$ test (excluding instruments and workforce). In Belgium, an antigen test is reimbursed 8.06€ per target (maximum 3) and a viral culture, 45.17€. The savings will likely balance the costs of performing a PCR instead of RDTs and viral cultures for inpatients during seasonal epidemic.

This study was prematurely interrupted by the surge of the COVID-19 pandemic in Belgium in March 2020, preventing us to evaluate the added value of the use of the cobas $^{\circledR}$ Liat $^{\circledR}$ Influenza A/B \& RSV assay as a POCT. It also prevented us to cross check PCR-only positive tests with another molecular method leading here to a likely underestimation of the specificity. However, the pandemic allowed us to use the cobas ${ }^{\circledR}$ Liat $^{\circledR}$ SARS-CoV-2 \& Influenza A/B assay as a POCT in the ER. This implementation raised biosafety concerns, as this assay requires the transfer by pipetting of the transport medium to the reagent tube, which can be considered as a projection and lead to aerosolization risks. To solve this, the loading of the reagent tube with the UTM was done at bedside, by the operator performing the sampling wearing personal protection equipment. The sealed tube was then transported to the instrument located in a separate room (17).

In conclusion, using a rapid molecular assay such as the cobas ${ }^{\circledR}$ Liat ${ }^{\circledR}$ Influenza A/B \& RSV assay for use on the cobas ${ }^{\circledR}$ Liat $^{\circledR}$ PCR system improves the clinical management of patients by refining the indications of isolation, antibiotic and antiviral treatment thanks to better analytical performances than RDTs. Using this instrument as a POCT in the ER could provide an efficient $24 / 7$ solution to swiftly and optimally dispatch inpatients and take at-risk outpatients in charge. 
medRxiv preprint doi: https://doi.org/10.1101/2021.11.18.21264071; this version posted November $20,2021$. The copyright holder for this preprint (which was not certified by peer review) is the author/funder, who has granted medRxiv a license to display the preprint in perpetuity.

It is made available under a CC-BY-ND 4.0 International license .

\section{References}

1. Vandenberg O, Martiny D, Rochas O, van Belkum A, Kozlakidis Z. Considerations for diagnostic COVID-19 tests. Nat Rev Microbiol. mars 2021;19(3):171?83.

2. Sheridan C. Coronavirus testing finally gathers speed. Nat Biotechnol [Internet]. 5 nov 2020 [cité 20 déc 2020]; Disponible sur: http://www.nature.com/articles/d41587-020-00021-z

3. Maltezou HC. Nosocomial influenza: new concepts and practice: Curr Opin Infect Dis. août 2008;21(4):337回 43.

4. Bont L. Nosocomial RSV infection control and outbreak management. Paediatr Respir Rev. juin 2009;10:16?7.

5. Nomenclature des prestations de santé [Internet]. Sect. Biologie Clinique - Article 24. Disponible sur: https://www.inami.fgov.be/SiteCollectionDocuments/nomenclatureart24_20210701_01.pdf

6. Chartrand C, Leeflang MMG, Minion J, Brewer T, Pai M. Accuracy of Rapid Influenza Diagnostic Tests: A Meta-analysis. Ann Intern Med. 3 avr 2012;156(7):500.

7. Chartrand C, Tremblay N, Renaud C, Papenburg J. Diagnostic Accuracy of Rapid Antigen Detection Tests for Respiratory Syncytial Virus Infection: Systematic Review and Meta-analysis. Tang Y-W, éditeur. J Clin Microbiol. déc 2015;53(12):3738? 49.

8. Lee BY, McGlone SM, Bailey RR, Wiringa AE, Zimmer SM, Smith KJ, et al. To Test or to Treat? An Analysis of Influenza Testing and Antiviral Treatment Strategies Using Economic Computer Modeling. Galvani AP, éditeur. PLoS ONE. 23 juin 2010;5(6):e11284.

9. Gibson J, Schechter-Perkins EM, Mitchell P, Mace S, Tian Y, Williams K, et al. Multi-center evaluation of the cobas ${ }^{\circledR}$ Liat ${ }^{\circledR}$ Influenza A/B \& RSV assay for rapid point of care diagnosis. J Clin Virol. oct 2017;95:5?9.

10. European Centre for Disease Prevention and Control. Factsheet about seasonal influenza [Internet]. [cité 27 juill 2021]. Disponible sur: https://www.ecdc.europa.eu/en/seasonalinfluenza/facts/factsheet

11. Centers for Disease Control and Prevention. Influenza Antiviral Medications: Summary for Clinicians [Internet]. [cité 27 juill 2021]. Disponible sur: https://www.cdc.gov/flu/professionals/antivirals/summary-clinicians.htm

12. Banoo S, Bell D, Bossuyt P, Herring A, Mabey D, Poole F, et al. Evaluation of diagnostic tests for infectious diseases: general principles. Nat Rev Microbiol. déc 2010;8(S12):S16?28.

13. Bonner AB, Monroe KW, Talley LI, Klasner AE, Kimberlin DW. Impact of the Rapid Diagnosis of Influenza on Physician Decision-Making and Patient Management in the Pediatric Emergency Department: Results of a Randomized, Prospective, Controlled Trial. PEDIATRICS. 1 août 2003;112(2):363? 7. 
medRxiv preprint doi: https://doi.org/10.1101/2021.11.18.21264071; this version posted November 20, 2021. The copyright holder for this preprint (which was not certified by peer review) is the author/funder, who has granted medRxiv a license to display the preprint in perpetuity.

It is made available under a CC-BY-ND 4.0 International license .

14. Rahamat-Langendoen J, Groenewoud H, Kuijpers J, Melchers WJG, Wilt GJ. Impact of molecular point-of-care testing on clinical management and in-hospital costs of patients suspected of influenza or RSV infection: a modeling study. J Med Virol. août 2019;91(8):1408?14.

15. Impact of Rapid Diagnosis on Management of Adults Hospitalized With Influenza. Arch Intern Med. 26 févr 2007;167(4):354.

16. Busson L, Bartiaux M, Brahim S, Konopnicki D, Dauby N, Gérard M, et al. Contribution of the FilmArray Respiratory Panel in the management of adult and pediatric patients attending the emergency room during 2015-2016 influenza epidemics: An interventional study. Int J Infect Dis. juin 2019;83:32 ?9.

17. Yin N, Debuysschere C, Decroly M, Bouazza F-Z, Collot V, Martin C, et al. SARS-CoV-2 Diagnostic Tests: Algorithm and Field Evaluation From the Near Patient Testing to the Automated Diagnostic Platform. Front Med. 2021;8:650581.

18. van Dijk MD, Voor in 't holt AF, Polinder S, Severin JA, Vos MC. The daily direct costs of isolating patients identified with highly resistant micro-organisms in a non-outbreak setting. J Hosp Infect. mars 2021;109:88?95. 